\title{
The Effect of Brand Image, Product Prices, and Product Quality on Repurchases of Kopi Petani Nusantara (Case Study on Kopi Petani Nusantara Consumers in Jakarta) \\ Sista Ferida Rotua Butar Butar ${ }^{1}$, Jerry Heikal ${ }^{2}$ \\ 1,2Magister Management Department, University of Bakrie, Jakarta, Indonesia
}

\begin{abstract}
Article Info

Volume 8, Issue 6

Page Number : 271-280

Publication Issue

November-December-2021

Article History

Accepted : 20 Nov 2021

Published : 30 Nov 2021

The high interest in coffee consumption in Indonesia is not only a coffeeproducing country, as quite a lot of consumers. Indonesia was ranked 4th as the world's largest coffee producer in 2016 after Brazil, Vietnam, and Colombia. Of the many types of coffee, in general, there are two types of coffee marketed in Indonesia, namely Arabica coffee and Robusta coffee. This research was conducted using quantitative methods with a population and sample of 112 respondents. The data analysis method used is binomial logistic regression analysis. The results showed that the quality of brand image, product price, and product quality are factors that determine repurchase decisions on Kopi Petani Nusantara in the archipelago, which shows $57.1 \%$ to be the determining factor while the rest is determined by other factors. This happens because of the better brand image of a product, so buyers will make repeat purchases to meet their needs, both in terms of Recognition, Reputation, Affinity, and Domain.

Keywords: Decision, Exhibition, Investment, Promotion, Factors
\end{abstract}

\section{INTRODUCTION}

Coffee is a drink brewed by coffee beans that have been roasted and ground into powder. Coffee is one of the commodities in the world that is cultivated in more than 50 countries. Two commonly known species of coffee trees are Robusta Coffee (Coffea canephora) and Arabica Coffee (Coffea arabica). The highest growth occurred the last year 2018/19$2019 / 20$, which was $13.9 \%$. It is estimated that from 2016-2021, coffee consumption will grow by an average of $8.22 \%$ per year. In 2021 , the coffee supply is predicted to reach 795 thousand tons with a consumption of 370 thousand tons, resulting in a surplus of 425,000 tons. https://bixbux.com/bisniscoffee-shop/. On the other hand, people have an interest in contemporary coffee and will open up business opportunities to expand their business and expand their business area. In fact, according to a report by PT Toffin and Mix Marketing \& Communication data in 2016, the number of coffee shop outlets was 1,083 units. In 2019, the number has reached more than 2,937 units. It is estimated that the number of coffee shop outlets has almost tripled. Here the author as the founder of Indonesian coffee farmers sees that there is a business opportunity in 
the development of coffee trends and until now Indonesian coffee farmers have been successfully sold through the online system (Tokopedia, Shopee) and Directly.

\section{A. Repurchase}

Consumers have three types of purchases, namely, trial purchases, repeat purchases, and long-term commitment purchases, which usually indicate that existing products are in accordance with consumer needs and consumers are willing to reuse them even in large quantities (Putriani, 2019). After consumers buy the product, satisfied customers will return to buy the product and even praise it in front of others and vice versa if not satisfied then there will be no repeat purchases.

The decision to repurchase (Repurchase Intention) shows the customer's desire for the future. Repurchase behavior is usually often associated with brand loyalty. Loyalty is only to reflect or illustrate the psychological commitment between consumers to a brand, while repeat purchases are made by consumers to buy a brand repeatedly. (Tjiptono, 2014). Repurchase Decision Indicators According to Keller (2016) repurchase decisions can be identified through the following indicators:

1. Transactional: namely the tendency of customers to repurchase a product that has been consumed.

2. Referential: namely the tendency of customers to refer products that have been purchased, so that other people also buy, with reference to their consumption experience.

3. Preferential: Behavior is described as consumers who always have a primary preference for the products they consume. This preference can only be changed if there is a problem with the selected product

4. Explorative: Behavior is described as consumers who are always looking for information about the products they are interested in and looking for information that supports the positive characteristics of the products they subscribe to.

\section{B. Brand image}

Brand image is the consumer's perception of the brand of a product that is formed from information obtained by consumers through the experience of using the product. According to Keller (2016. Brand image is a belief that is formed in the minds of consumers about the object of the product that has been felt and can lead to positive perceptions and consumer confidence in the product or service, thereby increasing brand loyalty. or a strong brand image can provide a major advantage). one can create a competitive advantage.

The image of a brand cannot be implanted directly in the minds of consumers through one medium in a short time, and the image of a brand must be communicated to consumers through various communication media that are available and disseminated repeatedly. Strong It is difficult for the company's image to attract new customers and buy the company's products and retain existing customers (Kotler and Armstrong, 2016)

According to Kotler, a brand has six levels of meaning, namely:

1. Attributes. Brands will first enhance people's attributes for a particular product.

2. Benefits, customers do not buy attributes, but the benefits of buying the product. Therefore, these attributes must be translated into functional and emotional benefits.

3. Value, the brand also reflects the value of the product manufacturer.

4. Culture, a brand represents a certain culture

5. Personality, the brand can be projected on a certain personality.

6. Users, the type of customer the brand recommends to buy the product. 


\section{Product Quality}

Kotler and Armstrong (2016) reveal that product quality is how a product has physical and psychological values that can satisfy consumers and refers to the attributes or characteristics contained by an item or result. Product development involves determining the benefits to be delivered. These benefits are conveyed through product attributes, namely: Product quality has two dimensions, namely level, and consistency. If a product can perform its function, it can be said that the product is of good quality. Product quality dimensions.

Dimensions of Product Quality According to Hestanto's Tjiptono (2019), there are several dimensions of product quality, including:

1. Performance is the main operating and product characteristics purchased. For examples speed, ease of use, and ease of use.

2. Durability, i.e. durability shows the service life of the product, namely the number of uses of the product before it is replaced or damaged. The longer the durability, and of course the longer it lasts, the durable products will be considered to be of higher quality than products that run out or are quickly replaced.

3. Conformance to specifications, namely conformity, namely the extent to which the design and operating characteristics meet predetermined standards. For example, quality control and design, operational characteristics standards are the conformity of product performance with stated standards of a product.

4. Features are those that complement the basic benefits of the product. This function is optional or optional for consumers.

5. Reliability is less likely to be damaged or unusable. For example, quality control and design, standard operating characteristics meet specifications.
6. Aesthetics, namely the attractiveness of products to the five senses, such as physical form, artistic models or designs, colors, etc.

7. Perceived quality, namely consumer perceptions of the overall quality or superiority of the product. Usually, due to the buyer's lack of understanding of the attributes or characteristics of the product purchased, the buyer perceives quality in terms of price, brand, advertising, company reputation, and country of manufacture. The company objected.

8. Serviceability, product quality is determined based on treatment, including speed, capacity, comfort, maintenance, and satisfactory complaint handling.

\section{Price}

Kotler and Armstrong (2016) say that price is a narrow sense is the fee charged for a product or service; More generally, price is the sum of all the values that customers give up to benefit from having or using a product or service. Andi (2015) argues that price is the main factor influencing buyer choice. Price plays an important role in determining consumer buying behavior. Therefore, before setting the price, the company must check the reference price of several products. There are four indicators that can be used to measure the price of an item according to Pepadri and Sitinjak (2019), namely:

1. Price reference

2. Relatively cheaper price

3. Reasonable price

4. The suitability of the sacrifice and the price according to the benefits.

\section{METHODS}

This research is explorative, the data acquisition technique is carried out by observation and literature study so that a hypothesis or conclusion is obtained. The purpose of exploratory research is to develop 
basic ideas/concepts about a new problem topic or whose origins are unknown at all.

\section{A. Respondent}

The respondents came from the age group of 22-27 and 28-35 years. In this age category, the majority of respondents are in their productive period and like to shop. Stomach health factors that are still prime can also be a factor.

\section{B. Data Collection}

The data collection method in this study used a questionnaire using a Likert scale, which is a scale that shows the same value in the measured characteristics (Sugiyono, 2016). A research study of census data in which the entire population is used as the research sample.

\section{Data Analysis}

Analysis of the data in this study using the Binominal Logistics Regression Test Analysis. Binominal Regression Logistics aims to determine the linear relationship between two or more independent variables (X1, X2, and X3) and the dependent variable (Y). This analysis is used to determine the direction of the relationship between the independent variable and the dependent variable if each independent variable has a positive or negative relationship and to predict the value of the dependent variable if the value of the independent variable will be determined. The Logistics Regression Model is:

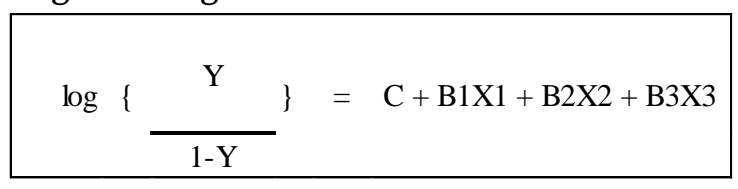

\section{RESULT AND DISCUSSION}

\section{A. Result}

\section{Validity test}

The results of the calculation of $r_{x y}$ or $r_{c o u n t}$ are compared with the $\mathrm{r}_{\text {tabel }}$ with a significant level of $5 \%$. If the value of $r_{\text {count }}$ is greater than $r_{\text {tabel, }}$, then the item can be said to be valid. According to Burhan (2016), the rabel with 34 respondents is 0.3291 . If the value of rcount is greater than 0.3291 then the item can be said to be valid. The following is a table of the results of the validity of the research instrument.

Table 4. 01

Validity Test X1 (Variable: Brand Image)

\begin{tabular}{|c|c|c|c|}
\hline Question & $\mathbf{r}_{\mathbf{x y}}$ & $\begin{array}{c}\mathbf{r}_{\text {table }} \mathbf{5 \%} \\
\mathbf{( 3 4 )}\end{array}$ & Description \\
\hline $\mathrm{X} 1.1$ & 0,765 & 0,3291 & Valid \\
\hline $\mathrm{X} 1.2$ & 0,682 & 0,3291 & Valid \\
\hline $\mathrm{X} 1.3$ & 0,791 & 0,3291 & Valid \\
\hline $\mathrm{X} 1.4$ & 0,722 & 0,3291 & Valid \\
\hline
\end{tabular}

Table 4.02

Validity Test X2 (Variable: Product Price)

\begin{tabular}{|c|c|c|c|}
\hline Question & $\mathbf{r}_{\mathbf{x y}}$ & $\begin{array}{c}\mathbf{r}_{\text {table }} \mathbf{5 \%} \\
\mathbf{( 3 4 )}\end{array}$ & Description \\
\hline $\mathrm{X} 2.1$ & 0,614 & 0,3291 & Valid \\
\hline $\mathrm{X} 2.2$ & 0,584 & 0,3291 & Valid \\
\hline $\mathrm{X} 2.3$ & 0,524 & 0,3291 & Valid \\
\hline $\mathrm{X} 2.4$ & 0,479 & 0,3291 & Valid \\
\hline
\end{tabular}

Tabel 4.03

Validity Test X3 (Variable : Product Quality)

\begin{tabular}{|c|c|c|c|}
\hline Question & $r_{x y}$ & $\begin{array}{c}\mathbf{r}_{\text {table }} 5 \% \\
-34\end{array}$ & Description \\
\hline $\mathrm{X} 3.1$ & 0,536 & 0,3291 & Valid \\
\hline X3.2 & 0,639 & 0,3291 & Valid \\
\hline X3.3 & 0,612 & 0,3291 & Valid \\
\hline
\end{tabular}

\section{Reliability Test}

The reliability of a research instrument is said to be good if it has a Cronbach's Alpha value $>0.60$

Tabel 4. 04

Reliability Test (X1)

\begin{tabular}{|c|c|}
\hline & Cronbach's Alpha \\
\hline $\mathrm{X} 1$ & .746 \\
\hline $\mathrm{X} 2$ & .739 \\
\hline $\mathrm{X} 3$ & .723 \\
\hline $\mathrm{Y}$ & .766 \\
\hline
\end{tabular}


From the table above, it is clear that the Cronbach's Alpha value is $>0.600$ so it can be said that it is reliable.

\section{Correlation Test}

Correlation analysis is used to determine the relationship between two or more independent variables on the dependent variable simultaneously. The value of $\mathrm{R}$ varies from 0 to 1 , a value close to 1 means the relationship is getting stronger, while a value close to 0 means the relationship is getting weaker. According to Sugiyono (2016), the guidelines that provide an interpretation of the correlation coefficient are as follows:

$$
\begin{aligned}
& 0.00-0.199=\text { very low } \\
& 0.20-0.399=\text { low } \\
& 0.40-0.599=\text { moderate } \\
& 0.60-0.799=\text { strong } \\
& 0.80-1,000=\text { very strong }
\end{aligned}
$$

The value of the correlation coefficient is determined by the value of $R$ as can be seen in the following table:

Tabel 4.05

\section{Correlation Matrix}

\begin{tabular}{|rl|r|r|r|r|}
\hline & & \multicolumn{1}{c|}{$\mathrm{Y}$} & \multicolumn{1}{c|}{$\mathrm{X} 1$} & \multicolumn{1}{c|}{ X2 } & \multicolumn{1}{c|}{ X3 } \\
\hline \multirow{4}{*}{ Step 1 } & $\mathrm{Y}$ & 1.000 & .737 & .739 & .541 \\
& $\mathrm{X} 1$ & .737 & 1.000 & .236 & .215 \\
& $\mathrm{X} 2$ & .739 & .236 & 1.000 & .144 \\
& $\mathrm{X} 3$ & .541 & .215 & .144 & 1.000 \\
\hline
\end{tabular}

Based on the table, the correlation for $\mathrm{X} 1$ to $\mathrm{Y}$ is $73.7 \%$, for $\mathrm{X} 2$ to $\mathrm{Y}$ is $73.9 \%$ and $\mathrm{X} 3$ to $\mathrm{Y}$ is $54.1 \%$. This shows that there is a moderate and strong relationship between the independent variable and the dependent variable. It can be seen that the X1 variable, namely brand image, has the highest correlation value on the repurchase decision variable.

\section{Determination Test}

The determination Test is used to see how the independent variables contained in the study are able to represent the factors that affect the dependent variable as a whole. The bigger the sig. The result means that the greater the ability of the independent variables contained in explaining the dependent variable. The following is the coefficient of determination using SPSS version 20 software:

Tabel 4.06

\section{Coefficient of Determination}

Model Summary

\begin{tabular}{|l|c|r|r|}
\hline Step & $\begin{array}{c}-2 \text { Log } \\
\text { likelihood }\end{array}$ & $\begin{array}{c}\text { Cox \& Snell R } \\
\text { Square }\end{array}$ & $\begin{array}{l}\text { Nagelkerke R } \\
\text { Square }\end{array}$ \\
\hline 1 & $59.053^{\mathrm{a}}$ & .524 & .728 \\
\hline
\end{tabular}

a. Estimation terminated at iteration number 7 because parameter estimates changed by less than .001 .

Based on the table, the value obtained is 0.728 . This shows that the variation in the behavior of the repurchase decision variable can be explained by the variable that the brand image (X1) price (X2) and quality (X3) are able to represent the repurchase decision variable $(\mathrm{Y})$ of $72.85 \%$. While the remaining $27.15 \%$ is explained by other variables not proposed in the study.

\section{Binomial Logistics Regression Test Analysis}

\begin{tabular}{|c|c|c|c|c|c|c|c|c|c|}
\hline \multicolumn{10}{|c|}{ Variables in the Equation } \\
\hline & & \multirow[t]{2}{*}{ B } & \multirow[t]{2}{*}{ S.E. } & \multirow[t]{2}{*}{ Wald } & \multirow[t]{2}{*}{ Df } & \multirow[t]{2}{*}{ Sig. } & \multirow[t]{2}{*}{$\operatorname{Exp}(\mathrm{B})$} & \multicolumn{2}{|c|}{\begin{tabular}{|l}
$95 \%$ \\
EXP(B)
\end{tabular}} \\
\hline & & & & & & & & Lower & Upper \\
\hline \multirow{4}{*}{ Step $1^{\mathrm{a}}$} & AVGX1 & 3.133 & .737 & 18.053 & 1 & .000 & 22.947 & 5.408 & 97.370 \\
\hline & AVGX2 & 2.600 & .764 & 11.596 & & .001 & 13.470 & 3.015 & 60.170 \\
\hline & AVGX3 & 1.361 & .473 & 8.261 & & .004 & 3.899 & 1.542 & 9.860 \\
\hline & Constant & -22.644 & 4.281 & 27.974 & 1 & .000 & .000 & & \\
\hline
\end{tabular}

Based on the results of the data test using SPSS, the following data were obtained

Tabel 4.07

Hasil Uji Data Menggunakan SPSS

It can be shown the following equation:

$\log (\mathrm{Y} / 1-\mathrm{Y})=-22.644+3.133 \mathrm{X}_{1}+2.600 \mathrm{X}_{2}+1.361 \mathrm{X}_{3}$ $\mathrm{Y}=1 /(1+\operatorname{EXP}(-(-22.644+3.33 \mathrm{X} 1,+2.600 \mathrm{X} 2+$ 1.361X3)))

Description :

$\mathrm{Y}^{\prime} \quad=$ Repurchase decision

$\mathrm{X} 1=$ Brand Image

$\mathrm{X}_{2}=$ Price

$\mathrm{X}_{2} \quad=$ Product Quality 


\section{Hypothesis test}

\section{T-test (Partial Significance)}

Hypothesis Test is Inferential Statistical Science which is used to test the truth of a statement statistically and draw conclusions whether to accept or reject the statement. Assumptions or temporary statements made to be tested for truth are also called hypotheses or hypotheses. The purpose of this hypothesis test is to determine a basis so that it can collect evidence in the form of good data in determining the decision whether to reject or accept the truth of the statements or assumptions that have been made. This hypothesis test also has confidence in objective decision-making.

One of the hypothesis tests is the t-test. The t-test in binomial logistic regression analysis aims to determine whether the independent variable $(X)$ partially has a significant effect on the dependent variable $(\mathrm{Y})$.

Tabel 4.08

T-Test Results (Partial Significance)

\begin{tabular}{|c|c|c|c|c|c|c|c|c|c|}
\hline \multicolumn{10}{|c|}{ Variables in the Equation } \\
\hline & & \multirow{2}{*}{ B } & \multirow{2}{*}{ S.E. } & \multirow{2}{*}{ Wald } & \multirow{2}{*}{$\mathrm{Df}$} & \multirow{2}{*}{ Sig. } & \multirow{2}{*}{$\operatorname{Exp}(\mathrm{B})$} & \multicolumn{2}{|c|}{$95 \%$ C.I.for EXP(B) } \\
\hline & & & & & & & & Lower & Upper \\
\hline \multirow{4}{*}{ Step $1^{\mathrm{a}}$} & $\overline{\mathrm{AVGX1}}$ & 3.133 & .737 & 18.053 & 1 & .000 & 22.947 & 5.408 & 97.370 \\
\hline & AVGX2 & 2.600 & .764 & 11.596 & 1 & .001 & 13.470 & 3.015 & 60.170 \\
\hline & AVGX3 & 1.361 & .473 & 8.261 & 1 & .004 & 3.899 & 1.542 & 9.860 \\
\hline & Constant & -22.644 & 4.281 & 27.974 & 1 & .000 & .000 & & \\
\hline
\end{tabular}

The results of the data analysis above can be interpreted as follows

\section{Brand Image}

If the value of sig $<0.05$, it can be interpreted that the amount of Brand Image partially has a significant effect on the Repurchase variable.

If the value of sig $>0.05$, it can be interpreted that the Brand Image variable partially does not have a significant effect on the Repurchase variable.

From the table above, it can be seen that the results of testing the hypothesis on the amount of Brand Image show a significance level of 0.000 . The significance value is smaller than 0.05 , which can be interpreted that the Brand Image partially has a significant positive determination on Repurchase.

\section{Product Price}

If the value of $\mathrm{sig}<0.05$, it can be interpreted that the amount of product price partially has a significant effect on the repeat purchase variable.

If the sig value $>0.05$, it can be interpreted that the product price variable partially does not have a significant effect on the repurchase variable.

From the table above, it can be seen that the results of testing the hypothesis of the product price value show a significance level of 0.001 . The significance value is smaller than 0.05 , which can be interpreted that the price of the product partially has a significant positive determination on Repurchase

\section{Product Quality}

If the value of sig $<0.05$, it can be interpreted that the amount of product quality partially has a significant effect on the Repurchase variable.

If the sig value $>0.05$, it can be interpreted that the product quality variable partially has no significant effect on the Repeat Purchase variable.

From the table above, it can be seen that the results of hypothesis testing on the product price value indicate a significance level of 0.004 . The significance value is smaller than 0.05 , which can be interpreted that the price of the product partially has a significant positive determination on Repurchase.

\section{F-Test (Simultaneous Significance)}

The F-Test is known as the simultaneous test or model test / ANOVA test, which is a test to see how the effect of all the independent variables together on the dependent variable. The degree of confidence used is 0.05 . If the calculated $f$ value is greater than the $f$ value according to the table, then the alternative hypothesis states that all independent variables simultaneously have a significant effect on the independent variables. 
Tabel 4.09

F Test Results (Simultaneous Significance)

Variables in the Equation

\begin{tabular}{|ll|l|r|r|r|r|r|}
\hline & B & S.E. & Wald & df & Sig. & Exp(B) \\
\hline Step 0 & Constant & -.707 & .201 & 12.370 & & 1.000 & .493 \\
\hline
\end{tabular}

The results of the $\mathrm{F}$ statistic test show a value of 12.370 with a significance of 0.000 . The significant value of $\mathrm{F}$ is less than 0.05 , thus $\mathrm{Ho}$ is rejected and $\mathrm{Ha}$ is accepted. This means that the simultaneous test shows that Brand Image (X1), Product Price (X2) and Product Quality (X3) together have a significant determination on Repurchase $(\mathrm{Y})$

\section{B. Discussion}

Based on data from questionnaires conducted to 112 respondents, they are consumers who have already purchased Kopi Farmers Nusantara. and based on research that has been carried out through the data processing process which was analyzed using SPSS Version 20 software, the following are the results of the research discussion based on the hypotheses that have been made previously: Based on data from questionnaires conducted to 112 respondents, they are consumers who have already purchased Kopi Farmers Nusantara. and based on research that has been carried out through the data processing process which was analyzed using SPSS Version 20 software, the following are the results of the research discussion based on the hypotheses that have been made previously:

1. The basis for decision-making in testing the hypothesis on the partial significant test is done by looking at the significance level. Based on the results of the study, the significant value of brand image from the coefficient table of 0.000 is smaller than 0.05. From the results of these studies, it can be concluded that brand image has a significant influence on repurchase. The brand image variable (X1) has a relationship seen from the correlation value of 0.7373 to the repurchase variable $(\mathrm{Y})$. So, it can be concluded that brand image (X1) has a significant effect of $73.7 \%$ on repeat purchases $(\mathrm{Y})$. This is in line with research conducted by Wajeeha Aslam (2018) and Muhammad Sidi Izzudin (2018) that brand image (X1) has a significant effect on the repurchase (Y). This happens because of the better brand image of a product, so buyers will make repeat purchases to meet their needs, both in terms of Recognition, Reputation, Affinity, and Domain. Based on the correlation test, it can be seen that the brand image variable has a correlation of $73.7 \%$ on purchasing decisions. The strongest dimension in $\mathrm{X} 1.3$ is 0.791 , which is Afiniti, which is a sense of pride in using coffee products by Indonesian farmers. This shows the brand image for the X1.3 dimension as one of the variables with the strongest influence on repurchase decisions.

2. The basis for decision-making in testing the hypothesis on the partial significant test is done by looking at the significance level. Based on the results of the study, the significant value of product quality from the coefficient table of 0.000 is smaller than 0.05. From the results of these studies, it can be concluded that product quality has a significant influence on repeat purchases. The product quality variable (X2) has a relationship seen from the correlation value of 0.739 to the repeat purchase variable $(Y)$. So, it can be concluded that product quality (X2) has a significant effect of $73.9 \%$ on repeat purchases (Y). This is in line with research conducted by Sakinah, (Suhaily, 2017) that product quality (X2) has a significant effect on repeat purchases $(\mathrm{Y})$. This happens because the customer will interpret the value of an item, if he feels that the item has a cheap exchange rate but provides a lot of benefits, he will make a repeat purchase. On the other hand, this study is not in line with (W.Sullivan, 2018) that product quality (X2) does not have a significant effect on repeat purchases $(\mathrm{Y})$. This difference may occur because it is influenced by the different scopes of research in terms of time and research location. 
3. The basis for decision-making in testing the hypothesis on the partial significant test is done by looking at the significance level. Based on the results of the study, the significant value of the product price from the coefficient table of 0.000 is smaller than 0.05. From the results of these studies, it can be concluded that the price of the product has a significant effect on repeat purchases. The product price variable (X3) has a relationship seen from the correlation value of 0.541 to the repeat purchase variable $(\mathrm{Y})$. So, it can be concluded that the product price (X3) has a significant effect of $54.1 \%$ on repeat purchases (Y). This is in line with research conducted by Sakinah, (Graciola, 2019) that the price of the product (X3) has a significant effect on the repurchase (Y). This happens because the customer will interpret the value of an item, if he feels that the item has a cheap exchange rate but provides a lot of benefits, he will make a repeat purchase. On the other hand, this study is not in line with (Praptiestrini, 2019) that the price of the product (X3) does not have a significant effect on the repurchase $(\mathrm{Y})$. This difference may occur because it is influenced by the different scopes of research in terms of time and research location.

4. The basis for decision making in hypothesis testing in the simultaneous test is already by determining whether the independent variables affect the dependent variable. Based on the SPSS output results show that the value of the variable in Equation table Sig is 0.000 smaller than the alpha value $(0.05)$, so it can be concluded that there is a significant influence between brand image $(\mathrm{X} 1)$, product price $(\mathrm{X} 2)$ and product quality (X3) to repurchase (Y). Brand image variables $(\mathrm{X} 1)$ and product prices (X2 have a relationship with a correlation value of 0.728 to the repeat purchase variable (Y). It can be concluded that the product price (X2) has a significant effect of $72.8 \%$ on repeat purchases $(\mathrm{Y})$.

\section{CONCLUSION}

Based on the results of the study, the conclusions of this study are as follows:

1. Brand Image has a significant positive effect on repurchase. The higher the brand image, there will be an increase in repurchase at Kopi Petani Nusantara.

2. The price of the product has a significant positive effect on repeat purchases. The higher the benefits of product prices owned by employees, there will be the increase in repurchasing at Kopi Petani Nusantara.

3. Product quality has a significant positive effect on repeat purchases. The higher the quality possessed by employees, there will be increased in repurchase at Kopi Petani Nusantara.

4. Simultaneously, brand image, product price, product quality have a significant effect on repurchasing at Kopi Petani Nusantara.

\section{REFERENCES}

[1]. Adinata Elwin Novaris. 2015. The Effect of Experience, Website Quality and Trust on Online Repurchase Decisions on the OLX Indonesia Site. Scientific articles. Perbanas College of Economics. Surabaya. Downloaded On January 4, 2017

[2]. Ahmad Falhan Nasith \& Drs. Wahyu Hidayat M.Si (2016). The Effect of Product Quality and Brand Awareness on Repurchase Decisions Through Consumer Satisfaction (Study on Yamaha Vixion Consumers PT. Mataram Sakti Setiabudi)

[3]. Andanawati Aninda, R. 2014. The Effect of Price, Location, and Product Quality on Purchase Decisions (Case Study on Stove Syndicate Cafe Semarang). Essay. Diponegoro University, Semarang. 
[4]. Anwar, Ayesha, Amir Gulzar, Fahid Bin Sohail, and Salman Naeem Akram. 2011. Impact Of Brand Image, Trust And Affect On Consumer Brand Extension Attitude: The Mediating Role Of Brand Loyalty. International Journal of Economics and Management Sciences 1 (5): 7

[5]. Armalinda, (2019). The Effect of Store Image and Promotion on Repurchase Decisions Through Consumer Satisfaction (Study on Blueberry Lahat Stores). Untidar Recommendation Journal 2019.

[6]. Aslam, W. (2018). Influencing factors of brand perception on consumers' repurchase intention: An examination of online apparel shopping. Journal of Contemporary Management Issues, Vol. 23 No. 2.

[7]. Bilson, Simamora. 2011. Winning the Market with Effective and Profitable Marketing. Jakarta: PT. Main Library Gramedia

[8]. Buchari Alma, (2011), Marketing Management and Service Marketing, Prints of Abandonment, Alfabeth, Bandung.

[9]. Dyah Ayu Anisha Pradipta, 2012, The Effect of Brand Image on Consumer Loyalty of PT Pertamina (Persero) Enduro 4T Lubricating Oil Products in Makassar, Department of Management, Faculty of Economics and Business, Hasanuddin University, Makassar

[10]. Ekawati, Desi Retno. 2014. "Analysis of the Effect of Product Quality, Price Perception, and Brand Image on the Purchase Decision of Olive Fried Chicken Tembalang". Semarang : Diponegoro University Management

[11]. Fajarinto, Bayu, Nawazirul Lubis, and Saryadi (2013). The Influence of Service Quality and Brand Image on Customer Loyalty through Customer Satisfaction (Case Study on CV. AHASS Sahabat Sejati Motor Tembalang Semarang), Diponegoro Journal of Social and Politic, p. 1-12
[12]. Ghozali. (2017). Application of Multivariate Analysis With IBM SPSS Program 23. Semarang: Diponegoro University.

[13]. Graciola (2019). Does price sensitivity and price level influence store price image and repurchase intention in retail markets?

[14]. Graciola, A. P. (2019). Does price sensitivity and price level influence store price image and repurchase intention in retail markets? Journal of Retailing and Consumer Services.

[15]. Haryadi, F. T. 2002. Study on The Diffusion Process of Agricultural Technology Innovation. Science of Plant and Animal Production, Management and Economics of Agriculture and Forestry. United Graduate School of Agricultural Science, Tokyo University of Agriculture and Technology, Tokyo.

[16]. Hidayah, Nurul. 2017. "Development of ComicBased Learning Media in Social Science Subjects Class IV MI". Journal of Basic Education and Learning. Vol. 4, No. 1.

[17]. Ian Antonius Ong And Drs. Sugiono Sugiharto, M.M (2013). Analysis of the Effect of Differentiation Strategy, Brand Image, Product Quality and Price on Customer Purchase Decisions at Cincau Station Surabaya

[18]. Irma Yanti Febrini, Retno Widowati PA, Misbahul Anwar. (2019) The Effect of Experiential Marketing on Consumer Satisfaction and Repurchase Decisions at Klotok Coffee Shops, Kaliurung, Yogyakarta

[19]. Ishmah Parameswari Hafi, Naili Farida, \& Widiartanto (2015). The Effect of Perceived Quality and Store Environment on Repurchase Decisions Through Experiential Marketing as Intervening Variables (Study on Customers

[20]. IZZUDIN, M. S. (2018). The Effect Of Perceived Quality, Brand Image On Customer Satisfaction And Brand Awareness Toward Repurchase Intention. Journal of Research in Management. 
[21]. Kotler P., \& Keller KL., (2016), Marketing Management: Edition 14, New Jersey: Pearson Education, Inc.

[22]. Melka Neria .S (2012). The Effect of Brand Image on Consumer Loyalty of Garuda Indonesia Airlines. Depok : Faculty of Social and Political Sciences, University of Indonesia.

[23]. Muhammad Sidi Izzudin. (2018) Influencing factors of brand perception on consumers repurchase intention: An examination of online apparel shopping

[24]. Praptiestrini (2019). The Effect of Shopee eService Quality and Price Perception on Repurchase Intention: Customer Satisfaction as Mediation Variable

[25]. Praptiestrini. (2019). The Effect of Shopee eService Quality and Price Perception on Repurchase Intention: Customer Satisfaction as Mediation Variable. Journal of Contemporary Management Research.

[26]. Soelasih. Suhaily. 2017. What Effect Repurchase Intention Of Online Shopping. International Business Research. Vol. 10, No. 12

[27]. Suhaily, L. (2017). What Effects Repurchase Intention of Online Shopping. International Business Research.

[28]. Sullivan, Yulia W, and Dan J Kim. 2018. "Assessing the Effects of Consumers' Product Evaluations and Trust on Repurchase Intention in E-Commerce Environments.” International Journal of Information Management 39:199219.

[29]. W. Sullivan, Y. (2018). Assessing the effects of consumers' product evaluations and trust on repurchase intention in e-commerce environments. International Journal of Information Management.

[30]. Wajeeha Aslam. (2018) Influencing factors of brand perception on consumers' repurchase intention: An examination of online apparel shopping
[31]. Wijayajaya (2019). The Effect of Trust and Brand Image to Repurchase Intention in Online Shopping

[32]. Wijayajaya, H. R. (2019). The Effect of Trust and Brand Image to Repurchase Intention in Online Shopping. International Conference on Economics, Business and Economic Education.

\section{Cite this article as :}

Sista Ferida Rotua Butar Butar, Jerry Heikal, "The Effect of Brand Image, Product Prices, and Product Quality on Repurchases of Kopi Petani Nusantara (Case Study on Kopi Petani Nusantara Consumers in Jakarta)", International Journal of Scientific Research in Science and Technology (IJSRST), Online ISSN : 2395-602X, Print ISSN : 2395-6011, Volume 8 Issue 6, pp. 271-280, November-December 2021. Available at doi : https://doi.org/10.32628/IJSRST218623 Journal URL : https://ijsrst.com/IJSRST218623 